\begin{tabular}{|c|c|}
\hline 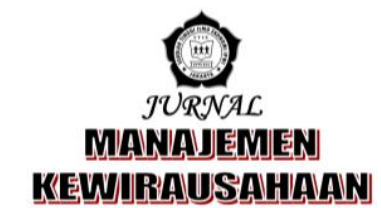 & $\begin{array}{r}\text { p-ISSN 1858-1048 } \\
\text { e-ISSN 2654-9247 } \\
\text { http://ejurnal.stieipwija.ac.id/index.php/jmk } \\
\text { DOI: http://dx.doi.org/10.33370/jmk.v17i1.395 } \\
\text { Jurnal Manajemen Kewirausahaan Vol. 17 No. 01 - Juni } 2020 \\
\text { Submit: 01 Mei 2020; Review: 03 Mei 2020; Publish: 30 Jun } 2020\end{array}$ \\
\hline
\end{tabular}

\title{
EFISIENSI NERACA MODAL DAN NERACA FINANSIAL PADA NERACA PEMBAYARAN INDONESIA (NPI) TAHUN 2015-2017
}

\section{(EFFICIENCY OF CAPITAL AND FINANCIAL ACCOUNTS IN THE INDONESIA'S BALANCE OF PAYMENT PERIOD 2015-2017)}

\author{
Oleh: \\ Miralda Indiarti'1), Cecep Sidin'2), Yoyo Indah Gunawan ${ }^{3)}$ \\ miralda89@yahoo.com ${ }^{1}$, cecep_sidin@yahoo.co.id²),yoyogunawan67@gmail.com ${ }^{3}$ ) \\ Sekolah Tinggi Ilmu Ekonomi IPWI Jakarta1,2,3)
}

\begin{abstract}
This study discusses the effectiveness of the capital balance and financial balance in 2015-2017 per quarter. This study uses the Data Envelopment Analysis (DEA) Program to prove the effectiveness of the Capital Balance and Financial Balance in the Indonesia Balance of Payments (NPI). The output used is the NPI, input 1 capital account balance, input 2 financial balance, 9 units of the Decision Making Unit. Secondary data sourced from BI Report. Balance of Payments that have returns for increasing returns to scale (IRS) of 2 periods (9.8\% and 59.4\%), decreasing return to scale (DRS) of 6 periods (above 80\%), and constant return to scale (CRS) only 1 period (100\%). In the 6th period, there was an efficiency of constant return to scale of $100 \%$, where the balance of payments output in the first quarter of 2017 was considered efficient at US \$4,514 million with capital balance input of US \$1 million and financial balance of US $\$ 6.652$ million. Suggestions for improving the balance of payments that have not been efficient by reducing inputs, namely the financial balance in order to achieve 100\% efficiency.
\end{abstract}

Keywords: Efficiency, Capital Accounts, Financial Accounts, Indonesian Payment Balance

\begin{abstract}
ABSTRAK
Penelitian ini membahas keefektifan neraca modal dan neraca finansial pada tahun 2015-2017 per triwulan. Penelitian ini menggunakan program Data Envelopment Analysis (DEA) untuk membuktikan efektifitas neraca modal dan neraca Finansial dalam Neraca Pembayaran Indonesia (NPI). Output yang digunakan adalah NPI, input 1 neraca modal, input 2 neraca finansial, Decision Making Unit sejumlah 9 unit. Data sekunder bersumber dari laporan BI. Neraca pembayaran yang memiliki tingkat pengembalian berupa increasing return to scale (IRS) sebanyak 2 periode $(9,8 \%$ dan $59,4 \%$ ), decreasing return to scale (DRS) sebanyak 6 periode (diatas 80\%), dan constant return to scale (CRS) hanya 1 periode (100\%). Periode ke 6 terjadi efisiensi constant return to scale sebesar 100\% dimana output Neraca Pembayaran pada triwulan 1 tahun 2017 dianggap efisien sebesar US\$ 4,514 juta dengan input neraca modal US\$ 1 juta dan neraca financial sebesar US\$ 6,652 juta. Saran perbaikan untuk neraca pembayaran yang belum efisien dengan mengurangi input yaitu neraca finansial agar mencapai efisiensi $100 \%$.
\end{abstract}

Kata Kunci: Efficiency, Capital Accounts, Financial Accounts, Indonesian Payment Balance 


\section{PENDAHULUAN}

Terdapatnya perbedaan sumber daya alam, iklim, sumber daya manusia dan modal membuat suatu Negara menghasilkan barang yang berbeda dengan Negara laiinya, sehingga dibutuhkan transaksi perdagangan internasional. Agar suatu Negara dapat memenuhi kebutuhan akan barang lainnya yang tidak dapat diproduksi oleh Negara tersebut.

Transaksi

Perdagangan

Internasional tercatat dalam Neraca Pembayaran Indonesia (NPI) atau Neraca Pembayaran Luar Negeri atau Balance of Payment (BOP).

Neraca Pembayaran Indonesia (NPI) triwulan III 2017 mengalami surplus yang meningkat ditopang oleh penurunan defisit transaksi berjalan dan peningkatan surplus transaksi modal dan finansial. Surplus NPI triwulan III 2017 tercatat USD5,4 miliar, meningkat signifikan dibandingkan dengan surplus triwulan II 2017 sebesar USD0,7 miliar. Surplus NPI tersebut mendorong peningkatan posisi cadangan devisa dari USD123,1 miliar pada akhir triwulan II 2017 menjadi USD129,4 miliar pada akhir triwulan III 2017. Jumlah cadangan devisa tersebut cukup untuk membiayai kebutuhan pembayaran impor dan utang luar negeri pemerintah selama 8,6 bulan dan berada di atas standar kecukupan internasional. Defisit transaksi berjalan tercatat sebesar USD4,3 miliar $(1,65 \%$ PDB) membaik dari defisit

Surplus transaksi modal dan finansial meningkat signifikan terutama didukung oleh besarnya arus modal masuk dalam bentuk investasi langsung, seiring dengan optimisme terhadap kinerja ekonomi domestik. Transaksi modal dan finansial pada triwulan III 2017 mencatat surplus USD10,4 miliar, meningkat signifikan dibandingkan dengan surplus triwulan II 2017 sebesar USD5,8 miliar dan juga lebih besar dibandingkan dengan surplus triwulan III 2016 sebesar USD9,9 miliar. Peningkatan surplus tersebut secara triwulanan didukung oleh meningkatnya surplus investasi langsung, sejalan dengan kenaikan realisasi investasi domestik, dan menurunnya defisit investasi lainnya, terutama karena turunnya outflow penempatan simpanan swasta domestik di luar negeri.

Peningkatan surplus transaksi modal dan finansial lebih lanjut tertahan oleh penurunan surplus investasi portofolio terutama karena keluarnya dana asing dari pasar saham domestic (Laporan Bank Indonesia)

Kinerja NPI diharapkan tetap baik sehingga dapat menopang ketahanan sektor eksternal. Bank Indonesia (BI) akan berusaha terus untuk memperkuat bauran kebijakan dalam menjaga stabilitas makroekonomi dan sistem keuangan, serta memperkuat koordinasi dengan Pemerintah dan otoritas terkait sehingga dapat meningkatkan ketahanan sektor eksternal, yaitu mendorong peningkatan Penanaman Modal Asing (PMA).

\section{TUJUAN PENELITIAN}

Dengan penelitian ini diharapkan:

1. Mengetahui unsur-unsur yang terdapat dalam Neraca Modal dan Neraca Finansial pada Neraca Pembayaran Indonesia (NPI).

2. Mengetahui pada periode tertentu tercapai Efisiensi Neraca Modal dan Neraca Finansial dalam Neraca Pembayaran Indonesia.

3. Mengetahui pada periode tertentu Neraca Modal dan Neraca Finansial masih belum efisien.

\section{TELAAH LITERATUR DAN PENGEMBANGAN PROPOSISI Efisiensi}

Hasil terbaik dari perbandingan antara hasil yang telah dicapai oleh suatu kerja dengan usaha yang dikeluarkan untuk mencapai hasil tersebut. Pendapatan ini menyatakan bahwa semakin tinggi hasil perbandingan antara output dan inputnya berarti tingkat efisiensi semakin tinggi. Dalam mengukur efisiensi, harus diketahui berapa banyak biaya yang 
harus ditanggung untuk mencapai suatu output tertentu. Ketika mengukur efektivitas harus diketahui apakah investasi tersebut dapat berguna.

Efisiensi untuk mendapatkan hasil output yang maksimal dari jumlah input yang sedikit. Efisiensi sering disebut sebagai "melakukan hal yang benar" yaitu, tidak menyia-nyiakan sumber daya”. (Robbins \& Mary, 2009)

\section{Neraca Pembayaran Indonesia (NPI)}

Neraca Pembayaran merupakan suatu catatan aliran keuangan yang menunjukkan nilai transaksi perdagangan dan aliran dana yang dilakukan diantara suatu Negara dengan Negara lain dalam suatu tahun tertentu (Sukirno, 2015:390). Dapat diartikan juga Ringkasan transaksi pada suatu Negara tertentu antara warga Negara domestik dan asing pada suatu periode tertentu. Pencatatan dalam Neraca Pembayaran Indonesia (NPI) menggunakan mata uang US dollar. Isi laporan Neraca Pembayaran yang paling penting adalah neraca berjalan dan neraca modal (Ekananda, 2015:264)

Laporan Neraca Pembayaran Indonesia bertujuan: 1) memperhitungkan defisit atau surplus kondisi keuangan Negara, 2) menjadi bahan pertimbangan dalam mengambil kebijakan perdagangan internasional, 3) bahan referensi untuk investor asing dalam memberikan pinjaman.

Neraca Pembayaran Indonesia (NPI) merupakan catatan statistik transaksi ekonomi antara penduduk Indonesia dengan bukan penduduk pada suatu periode tertentu. Transaksi NPI terdiri dari transaksi berjalan, transaksi modal, dan tnsaksi finansial. Sementara itu, Posisi Investasi Internasional Indonesia (PIII) merupakan statistik yang menunjukkan nilai aset dan kewajiban finansial Indonesia terhadap bukan penduduk dalam suatu titik waktu tertentu. Penyusunan Statistik NPI dan PIII dilakukan dengan mengacu pada the sixth edition of Balance of Payments and International Investment Position Manual (BPM6).

\section{Neraca Modal}

Transaksi modal (capital account): transaksi yang menyangkut investasi modal dan emas. Transaksi satu arah (bukan transaksi timbal balik) antara lain pemberian hadiah, bantuan (Ekananda, 2015:266). Neraca Modal meliputi 2 golongan yaitu aliran modal jangka panjang dan aliran modal swasta. Aliran modal meliputi aliran modal resmi dan investasi langsung oleh pihak swasta ke Negara-negara lain (Sadono Sukirno 2015:392).

Neraca Modal dibagi menjadi 3 bagian: 1) Investasi langsung yang terjadi ketika investor memperoleh suatu kontrol atas bisnis luar negeri. 2) Investasi Portofolio menunjukkan penjualan dan pembelian atas asset keuangan luar negeri. 3) Investasi lain yang meliputi transaksi dalam mata uang, deposito bank, kredit perdagangan, dan sebagainya.

\section{Neraca Finansial}

Aset finansial dapat berupa tagihan kepada bukan penduduk atau emas yang dimiliki sebagai bagian dari cadangan devisa. Transaksi ini timbul dengan sendirinya, tanpa dipengaruhi oleh transaksi lain, seperti transaksi berjalan, transaksi modal.

Perbedaan antara transaksi autonomus debit dan kredit diseimbangkan dengan transaksi "lalu lintas moneter". Yang termasuk dalam transaksi lalu lintas finansial adalah mutasi dalam hubungan dengan IMF, pasiva LN, aktiva LN (Tambunan, 2001:186)

\section{Penelitian Terdahulu}

Wulansari Fitri meneliti faktorfaktor yang mempengaruhi neraca transaksi berjalan Indonesia. Berdasarkan hasil penelitian diketahui bahwa variabel bebas yang mempengaruhi neraca transaksi berjalan Indonesia adalah kurs rupiah terhadap dolar Amerika Serikat dengan koefisien regresi sebesar 1.468. sedangkan variabel pengeluaran pemerintah dan pertumbuhan ekonomi dunia tidaksignifikan terhadap neraca transaksi berjalan Indonesia tahun 1990-2011. Upaya menyeimbangkan 
neraca transaksi berjalan dapat dilakukan dengan kebijakan stabilisasi nilai tukar rupiah di pasar valuta asing, pengurangan pengeluaran pemerintah dalam impor terutama impor migas, serta pembuatan peraturan yang memudahkan berkembangnya perdagangan internasional, dan pengembangan kerjasama di bidang ekonomi dan perdagangan sebagai upaya memecahkan masalah-masalah ekonomi dan perdagangan yang bersifat global.

Primatami dan Primadhita (2019). Menganalisis efisiensi kinerja UMKM makanan dengan menggunakan metode Data Envelopment Analysis (DEA). Hasil penelitian menemukan sebanyak tujuh UMKM atau $17,5 \%$ telah efisien selama bulan April 2019 sampai Juni 2019, sebanyak 10 UMKM atau 25\% memiliki nilai efisiensi yang berfluktuasi selama periode April 2019 sampai Juni 2019, dan sebanyak 23 UMKM atau 57,5\% belum mencapai efisien selama kurun waktu April 2019 sampai Juni 2019. Perbaikan untuk UMKM yang belum efisien, dilakukan dengan mengurangi input yang meliputi bahan mentah dan biaya tenaga kerja yang disesuaikan sehingga UMKM dapat mencapai tingkat efisiensi $100 \%$.

\section{Alur Penelitian}

Gambar 1

Alur Penelitian

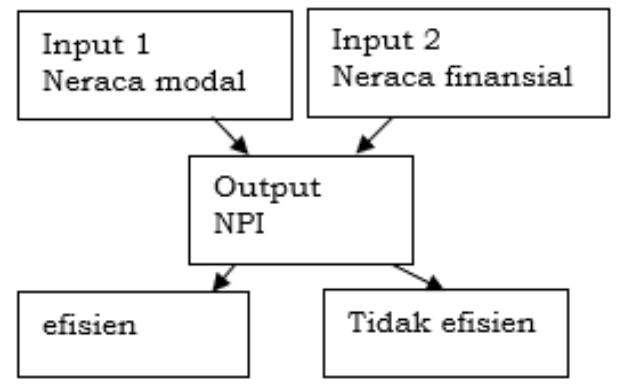

\section{METODE PENELITIAN}

Obyek Penelitian yang digunakan adalah Neraca Pembayaran Indonesia (NPI) terdiri Neraca Modal dan Neraca Finansial selama periode 2015-2017.

Neraca Pembayaran Indonesia suatu saat akan mencapai Efisiensi (100\%) yang dipengaruhi oleh input neraca modal dan input neraca finansial.

\section{Sampel Penelitian}

Data yang digunakan adalah data sekunder yaitu laporan Bank Indonesia tentang Neraca Pembayaran Internasional (NPI), Neraca Modal dan Neraca Finansial dari tirwulan ke 4 tahun 2015 sampai tahun 2017 per triwulan dipublikasikan oleh Bank Indonesia dalam website.

\section{Desain Penelitian}

Menggunakan input 1 neraca modal, input 2 neraca finansial. Output Neraca Pembayaran. DMU sebanyak 9 triwulan dari tahun 2015- 2017. Diambil dari Laporan Bank Indonesia melalui website

\section{Operasionalisasi Variabel}

Tabel 1

Operasionalisasi Variabel

\begin{tabular}{|l|l|l|}
\hline \multicolumn{1}{|c|}{$\begin{array}{l}\text { Variabel/ } \\
\text { Konsep }\end{array}$} & \multicolumn{1}{|c|}{ Indikator } & Skala \\
\hline Neraca Modal & $\begin{array}{l}\text {-Laporan } \\
\text { Bank }\end{array}$ & \\
& $\begin{array}{l}\text { Indonesia } \\
\text { periode } \\
\text { triwulan } \\
\text { 2015-2017 }\end{array}$ & US \$ \\
\hline \multirow{5}{*}{$\begin{array}{l}\text { Neraca } \\
\text { Finansial }\end{array}$} & $\begin{array}{l}\text {-Laporan } \\
\text { Bank } \\
\text { Indonesia } \\
\text { periode } \\
\text { triwulan } \\
\text { 2015-2017 }\end{array}$ & US \$ \\
\hline Neraca & $\begin{array}{l}\text { Laporan Bank } \\
\text { Indonesia } \\
\text { permbayaran } \\
\text { periode } \\
\text { triwulan } \\
\text { 2015-2017 }\end{array}$ & US \$ \\
\hline
\end{tabular}

\section{Metode Analisis}

Pengolaan

Envelopement data model Data Analysis DEA menggunakan perangkat lunak DEAP ver. 2.1 Data Envelopment Analysissis Program version 2.1) yang dikembangkan oleh Tim Coelli Centre for Efficiency and Productivity Analysis, Departement of Econometric, University of New England Australia. Dan, untuk mengelola statistika data 
menampilkan secara grafis dan tabular data menggunakan perangkat lunak Microsoft Excel 2007.

Hal-hal yang harus diperhatikan pada penggunaan DEA: a) Positivity, yang berarti DEA mensyaratkan semua variabel input dan output bernilai positif. b) Isotonicity, yang berarti setiap kenaikan variabel input apapun harus menghasilkan setidaknya satu variabel output dan tidak ada variabel output yang mengalami penurunan. c) Jumlah Decision Making Unit (DMU), minimal sebesar tiga kali dari jumlah variabel input dan output. d) Homogeneity, yang berarti DEA mensyaratkan seluruh DMU yang diteliti memiliki variabel input dan output yang sama jenisnya. e) Perbedaan-perbedaan tersebut. (Primatami, 2019).

Ada tiga manfaat yang diperoleh dari pengukuran efisiensi dengan DEA, diantaranya: 1. Sebagai tolak ukur untuk memperoleh efisiensi relatif yang berguna untuk mempermudah perbandingan antar unit ekonomi yang sama. 2. Mengukur berbagai variasi efisiensi antar unit ekonomi untuk mengidentifikasi faktor-faktor penyebabnya 3. Menentukan implikasi kebijakan sehingga dapat meningkatkan tingkat efisiensinya

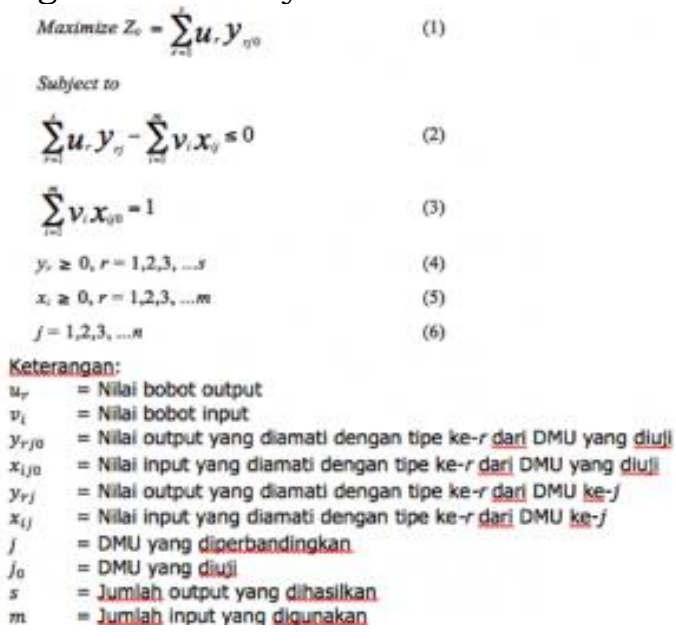

\section{HASIL DAN PEMBAHASAN Hasil Penelitian}

Dari hasil pengujian, didapat neraca pembayaran yang memiliki tingkat pengembalian berupa increasing return to scale (IRS) sebanyak 2 periode $(9,8 \%$ dan $59,4 \%$, decreasing return to scale (DRS) sebanyak 6 periode (diatas 80\%), dan constant return to scale (CRS) hanya 1 periode $(100 \%)$.

$\mathrm{Di}$ periode ke 6 terjadi efisiensi constant return to scale sebesar $100 \%$ dimana output Neraca Pembayaran pada triwulan 1 tahun 2017 dianggap efisien sebesar US\$ 4,514 juta dengan input neraca modal US\$ 1 juta dan neraca financial sebesar US\$ 6,652 juta.

\begin{tabular}{|c|c|c|c|}
\hline \multicolumn{4}{|c|}{ EFFICIENCY SUMMARY: } \\
\hline & Firm & crste & vrste scale \\
\hline 1 & 0.817 & 0.935 & $0.874 \mathrm{drs}$ \\
\hline 2 & 0.098 & 1.000 & $0.098 \mathrm{irs}$ \\
\hline 3 & 0.474 & 0.476 & $0.996 \mathrm{drs}$ \\
\hline 4 & 0.850 & 1.000 & $0.850 \mathrm{drs}$ \\
\hline 5 & 0.867 & 0.923 & $0.940 \mathrm{drs}$ \\
\hline 6 & 1.000 & 1.000 & $1.000-$ \\
\hline 7 & 0.204 & 0.343 & $0.594 \mathrm{irs}$ \\
\hline 8 & 0.824 & 0.958 & $0.860 \mathrm{drs}$ \\
\hline 9 & 0.202 & 0.208 & $0.970 \mathrm{drs}$ \\
\hline & & & $0.760 \quad 0.798$ \\
\hline
\end{tabular}

\section{FIRM BY FIRM RESULTS:}

Results for firm: 1

Technical efficiency $=0.935$

Scale efficiency $=0.874(\mathrm{drs})$

Results for firm: 2

Technical efficiency $=1.000$

Scale efficiency $=0.098$ (irs)

Results for firm: 3

Technical efficiency $=0.476$

Scale efficiency $=0.996(\mathrm{drs})$

Results for firm: 4

Technical efficiency $=1.000$

Scale efficiency $=0.850(\mathrm{drs})$

Results for firm: 5

Technical efficiency $=0.923$

Scale efficiency $=0.940(\mathrm{drs})$

Results for firm: 6

Technical efficiency $=1.000$

Scale efficiency $=1.000(\mathrm{crs})$

Results for firm: 7

Technical efficiency $=0.343$

Scale efficiency $=0.594$ (irs) 
Results for firm: 8

Technical efficiency $=0.958$

Scale efficiency $=0.860(\mathrm{drs})$

Results for firm: 9

Technical efficiency $=0.208$

Scale efficiency $=0.970(\mathrm{drs})$

\section{Pembahasan}

Hasil penelitian didapat Neraca Pembayaran yang memiliki tingkat pengembalian berupa increasing return to scale (IRS) sebanyak 2 periode $(9,8 \%$ dan $59,4 \%$ ), decreasing return to scale (DRS) sebanyak 6 periode (diatas 80\%), dan constant return to scale (CRS) hanya 1 periode $(100 \%)$. Di sini terlihat hanya periode ke 6 yang mencapai tingkat efisensi $100 \%$ dimana input neraca modal sebesar US\$ 1juta dan input neraca finansial sebesar US\$ 6,652 juta. Data ini menunjukkan input neraca finansial lebih besar dimana hutang luar negeri lebih besar daripada modal atau investasi yang masuk.

Penelitian Wulansari

(2014)

mengenai perubahan pengeluaran pemerintah tidak terbukti memiliki pengaruh nyata terhadap neraca transaksi berjalan, karena proporsi pengeluaran pemerintah sebagian besar digunakan untuk belanja pegawai, pembayaran utang, biaya pembangunan, dana Dana Perimbangan (APBN 2007).

Hasil penelitian Anisa (2014) dari Universitas Riau menyatakan bahwa exchange rates, gross domestic product, and net exports bersama-sama secara simultan mempengaruhi BOP dengan angka $52.3 \%(\mathrm{R} 2=0.523)$, dan sisanya $47.7 \%$ dipengaruhi variabel lainnya yang tidak dibahas.

Transaksi modal dan finansial pada triwulan IV 2016 terdapat surplus yang cukup besar dan melampaui defisit transaksi berjalan. Surplus transaksi modal dan finansial triwulan IV 2016 tercatat sebesar USD6,8 miliar, terutama berasal dari surplus investasi lainnya sejalan dengan berlanjutnya repatriasi dana tax amnesty.

Neraca Pembayaran Indonesia (NPI) triwulan IV 2016 terdapat surplus sebesar USD4,5 miliar. Surplus NPI triwulan IV 2016 tersebut juga mendorong kenaikan posisi cadangan devisa menjadi sebesar USD116,4 miliar pada akhir triwulan IV 2016, lebih tinggi dari USD115,7 miliar pada akhir triwulan III 2016 atau bila dibandingkan periode akhir triwulan IV 2015 yang sebesar USD105,9 miliar. Cadangan devisa tersebut cukup untuk membiayai kebutuhan pembayaran impor dan utang luar negeri pemerintah selama 8,4 bulan dan berada di atas standar kecukupan internasional. Untuk keseluruhan tahun. Surplus Neraca Pembayaran Indonesia (NPI) berlanjut triwulan IV 2017 defisit transaksi berjalan tetap terkendali. NPI surplus sebesar USD1,0 miliar disumbang surplus transaksi modal dan finansial, terutama bersumber dari investasi langsung dan investasi portofolio.

Hasil surplus NPI, posisi cadangan devisa meningkat dari USD129,4 miliar pada akhir triwulan III 2017 menjadi USD130,2 miliar pada akhir triwulan laporan.

\section{KESIMPULAN Kesimpulan}

Dari pembahasan dapat diambil kesimpulan hanya satu periode yang mencapai tingkat efisensi sebesar $100 \%$ yaitu di periode ke 6 dimana output Neraca Pembayaran pada triwulan 1 tahun 2017. Tidak setiap periode Neraca Pembayaran Indonesia (NPI) bisa mencapai tingkat efisiensi, dimana kedua input saling mempengaruhi. Apabila input 2 yaitu neraca finansial dikurangi dan input 1 yaitu neraca modal ditambah maka akan tercapai tingkat efisiensi $100 \%$, begitu juga sebaliknya.

\section{Saran}

Dari kesimpulan dapat diberikan saran sebagai berikut tingkat efisiensi Neraca Pembayaran tidak selalu dapat dicapai pada tiap periode atau tiap triwulan menurut Laporan Bank Indonesia. Tingkat efisiensi dapat dicapai dengan mengurangi input yaitu input 2 dan menambah input 1 yaitu 
menambah neraca modal dengan investasi terutama dari luar negeri yang dianggap menguntungkan. Mengurangi input 2 yaitu neraca finansial yang terdiri dari hutang luat negeri secara tidak langsung biasanya dipakai untuk menutupi deficit transaksi berjalan.

\section{DAFTAR PUSTAKA}

Alisman. 2014. Analisis efektivitas dan efesiensi manajemen keuangan di Aceh Barat. Jurnal Ekonomi dan Kebijakan Publik Indonesia, 1 (2).

Anisa, C. A. 2014. Faktor-faktor yang mempengaruhi neraca pembayaran Indonesia. JOM Fekon, 4 (1).

Mahyus, E. 2014. Ekonomi Internasional. Jakarta: Penerbit Erlangga.

Primatami, A., Primadhita, Y. 2020. Efisiensi umkm makanan dengan pendekatan data envelopment analysis. Jurnal Pengembangan Wiraswasta, 22 (1):1-10.

Sukirno, S. 2015. Makroekonomi teori pengantar. Jakarta: PT Raja Grafindo Persada.

Tambunan, T. 2011. Perekonomian indonesia kajian teoritis dan analisis empiris, Bogor: Ghalia Indonesia.

Wulansari, F. 2014. Analisis faktorfaktor yang mempengaruhi neraca transaksi berjalan: studi kasus indonesia tahun 1990-2011. Economics Development Analysis Journal, 3 (1). 
